\title{
Agnieszka Kubiczek
}

Uniwersytet Jagielloński

\section{FAZY PRZETWARZANIA INFORMACJI JĘZYKOWYCH W NAUCE OBCOJĘZYCZNEGO SŁOWNICTWA}

\begin{abstract}
The phases of vocabulary learning
In the article I am presenting the course of the process of learning vocabulary activated while teaching a foreign language. The paper takes the models of information processing and input processing as a starting point to describe the phases of vocabulary learning and to implicate the teaching procedures based on the insights in the natural processes of language acquisition. It provides theoretical background referring to the concept of instructed learning understood as the possibility of steering learners' perception and processing of lexical structures by the teacher, and also examples on how to use this knowledge in the classroom.
\end{abstract}

\section{Wstęp}

Glottodydaktyka zajmuje się opisem procesów uczenia się i nauczania języka drugiego, a także czynników je determinujących, z uwzględnieniem specyfiki warunków nauczania zorganizowanego (Wilczyńska i Michońska-Stadnik, 2010: 20). Jej do pewnego stopnia interdyscyplinarny charakter wynika z faktu, iż sięga ona niejednokrotnie do innych dyscyplin naukowych badających poszczególne aspekty wymienionych procesów. Z drugiej strony glottodydaktyka odznacza się autonomią, ponieważ zaczerpnięte teorie przechodzą przez tzw. filtr glottodydaktyczny (Pfeiffer, 1986), czyli są weryfikowane według kryteriów określonych zgodnie z własnymi celami poznawczymi. Korzystając z koncepcji rozwiniętych przez nauki pokrewne trzeba pamiętać o tym, iż nie są one proste do połącznia ze sobą i zastosowania w glottodydaktyce, ponieważ nie zawsze dotyczą dokładnie tych samych zjawisk w tych samych kontekstach z uwzględnieniem tych samych 
czynników. Niemniej jednak można próbować stworzyć z ich pomocą spójne koncepcje odnoszące się do rzeczywistości glottodydaktycznej.

Wyniki badań poświęconych przyswajaniu języków służą nie tylko teoretycznemu modelowaniu procesów nauki języków obcych, ale stanowią także podstawę do opracowywania efektywnych metod nauczania. Zadaniem współczesnej dydaktyki jest umożliwienie i wspieranie naturalnych procesów przyswajania języka drugiego pomimo specyficznych, często niekorzystnych warunków panujących w zbiorowym instytucjonalnym nauczaniu języków obcych. Mimo odmiennych kontekstów nie stwierdzono bowiem zasadniczych różnic w strukturze procesu przyswajania języka drugiego (w warunkach naturalnych) i obcego (nauka sterowana; por. Sadownik, 1981: 21). Jakkolwiek proces ten jest dla każdego człowieka taki sam, to ma on charakter indywidualny - wszyscy przechodzą te same fazy, ale dana faza może mieć odmienny przebieg u poszczególnych osób. O ile częścią procesów przyswajania języka nie można sterować z zewnątrz, to w przypadku wielu struktur językowych można wpływać na przebieg ich nabywania, np. przyspieszać lub skracać pewne etapy nauki.

\section{Miejsce słownictwa w nauce języków obcych}

Wyobrażenie o nauce języka obcego sprowadza się najczęściej do przyswajania słownictwa i reguł gramatycznych. Także programy nauczania podają jako jeden z głównych celów rozwijanie kompetencji leksykalno-gramatycznej. Na nierozłączność tych dwóch elementów wskazuje opis kompetencji leksykalnej jako „wiedz[y] i umiejętności w zakresie stosowania słownictwa danego języka, na co składają się elementy leksykalne i gramatyczne" (Raczyńska, 2007: 172). Wiedza ta pozwala użytkownikowi języka rozumieć słowa i zwroty, zachowywać je w pamięci, wywoływać je z niej oraz stosować we własnych wypowiedziach, a więc obejmuje zarówno receptywną jak i produktywną znajomość słownictwa (por. Scherfer, 1988).

Kolejne skojarzenie z nauką słownictwa to pamięciowe opanowywanie dwujęzycznej listy wyrażeń i długotrwałe ćwiczenia utrwalające, zakończone odpytywaniem przez nauczyciela. W rzeczywistości zaniechano takiego postępowania wraz z odrzuceniem metody gramatyczno-tłumaczeniowej. Wzrost znaczenia kompetencji komunikacyjnej zmienił postrzeganie leksyki, albowiem założono, iż „umiejętność przekazu informacji jest najsilniej uzależniona od poziomu opanowania słownictwa" (Komorowska, 1982: 115). Jednak według Huneke i Steinig (2002: 146) także podejście komunikacyjne zaniedbywało pracę nad „słowami” na rzecz całościowych formułek gotowych do zastosowania w różnych sytuacjach komunikacyjnych. Od czasu, gdy postuluje się opracowywanie metod nauczania w oparciu o wiedzę o procesach przyswajania języka, coraz silniej podkreśla się konieczność wspierania naturalnego 
przebiegu procesów poznawania i zachowywania w pamięci słownictwa, a więc samodzielnego konstruowania znaczeń nowych wyrażeń $\mathrm{i}$ ich integrowania $\mathrm{z}$ indywidualnym systemem wiedzy uczącego się, tak by ten był zdolny rozumieć myśli i potrzeby innych oraz wyrażać własne intencje, używając struktury leksykalne stosownie do osoby rozmówcy i kontekstu sytuacyjnego.

\section{Nauka języka obcego jako przetwarzanie danych językowych}

Nauka to proces aktywnego przyswajania informacji (Kesseler, 2004: 17). W tym ujęciu nauka języka to odbiór, przetwarzanie i zachowywanie informacji tworzących system wiedzy językowej. Informacje to wewnętrzne reprezentacje mentalne, które powstają na bazie danych pochodzących z otoczenia interpretowanych w oparciu o kontekst, w jakim się pojawiły, a także o posiadaną wiedzę i dotychczasowe doświadczenie. Te pozwalają na analizę i umiejscowienie nowej informacji w sieci innych powiązanych z nią informacji w systemie wiedzy. Dzięki wielopoziomowemu przetworzeniu i zachowaniu w pamięci możliwe jest zastosowanie przyswojonych informacji w dalszych działaniach językowych. Znając funkcjonowanie ludzkiej kognicji, a więc m.in. sposób przetwarzania informacji językowych, można tak organizować proces nauki, by osiągnąć jak najlepsze efekty.

W procesie przetwarzania informacji Schmidt (1986: 3) wyróżnia następujące fazy:

$>$ zainteresowanie informacją;

$>$ przyjmowanie informacji;

$>$ analiza informacji;

$>$ zachowanie informacji;

$>$ reaktywacja zachowanej informacji;

$>$ zastosowanie informacji.

Osoba opanowująca dany język tworzy wiedzę językową przez przetwarzanie tzw. danych wejściowych, które są dostarczane przez otoczenie językowe, a więc wszystkie dochodzące do nas teksty pisane i mówione (input). Input zawiera struktury i reguły języka docelowego, na podstawie których uczący się stawia hipotezy o jego budowie i funkcjonowaniu, które weryfikuje w czasie działań językowych (słuchania i mówienia). Proces nabywania danej struktury opisuje Vogel (1989: 92-94) wyróżniając następujące fazy:

$>$ odbiór inputu;

$>$ dostrzeżenie struktury językowej;

$>$ postawienie hipotezy;

$>$ testowanie hipotezy;

$>$ zachowanie struktury $w$ indywidualnym systemie językowym; 
$>$ output, czyli zastosowanie struktury językowej.

Input jest przetwarzany selektywnie, tzn. mechanizm uczeniowy wybiera z odbieranego tekstu to, co następnie zostanie poddane analizie. A więc nie wszystko, co słyszymy czy widzimy, służy do konstruowania systemu językowego. Zdolność postrzegania człowieka jest ograniczona i dlatego z łańcucha dochodzących do nas sygnałów, możemy przetworzyć tylko część z nich, najczęściej te, które zostały przez nas z jakiegoś powodu zauważone. Powodem zwrócenia uwagi na dany element czy wzbudzenia zainteresowania nim może być wyróżnianie się spośród innych elementów, waga jego znaczenia dla zrozumienia większej jednostki informacyjnej czy po prostu jego nowość jako elementu dotąd nieznanego czy nienapotkanego. Aby nowa informacja mogła zostać przeanalizowana, musi ona być zrozumiała, tak by móc postawić hipotezę dotyczącą znaczenia, budowy i funkcjonowania struktury w kontekście językowym i sytuacyjnym (por. Wode, 1993: 268, Gass, 1997: 4).

W ten sposób każdy konstruuje swój indywidualny systemy wiedzy językowej. Dlatego dydaktycy zalecają, by nauczyciele nie podawali gotowych objaśnień, lecz tworzyli okazje sprzyjające samodzielnemu efektywnemu odkrywaniu struktur i reguł. Odpowiednie podanie materiału językowego oraz pokierowanie uczniem pozwala na szybkie i sprawne przetworzenie struktur językowych, dzięki czemu proces nauki nie polega na pokonywaniu długotrwałej drogi metodą prób i pomyłek, lecz zmierza prosto do celu. W oparciu o znajomość przebiegu procesu nabywania języka można opracować konkretne procedury odpowiadające kolejnym fazom nauki. Lewicka (2007: 67) proponuje następujący układ:

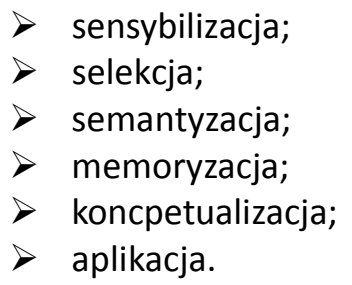

Punktem wyjścia w procesie nauki języka obcego jest aktywowanie posiadanych zasobów językowych, tak by ułatwić tworzenie nowej wiedzy. W fazie selekcji i semantyzacji uczeń przyjmuje nowe informacje kierując się ich wartością i poszukuje ich znaczenia. Zapamiętane treści stają się przedmiotem konstruowania własnych wyobrażeń odnośnie nowych informacji, które dotyczą najczęściej ram sytuacyjnych i sposobów werbalizacji, co ułatwia zastosowanie informacji w przyszłej komunikacji językowej.

\section{Nauka słownictwa obcojęzycznego}

Słowa to ciągi znaków, które niosą określone znaczenie przedmiotowe, a ich „funkcja i znaczenie wynikają z kontekstu, czyli bezpośredniego (poprzedzające- 
go i następczego) sąsiedztwa wyrazowego, oraz kontekstu syntagmatycznosyntaktycnzego" (Szczodrowski, 2002: 434). Przyswajanie struktury leksykalnej obejmuje zatem zasadniczo jej formę dźwiękową lub/i graficzną, znaczenie oraz cechy morfo-syntaktyczne, czyli jak zachowuje się dana forma w sąsiedztwie innych struktur językowych. Uczniowie uczą się nowych wyrażeń bądź to przez bezpośrednie odniesienie ich do opisywanych obiektów, czynności czy zdarzeń, bądź przez odbiór i aktywne przetwarzanie tekstów. Uczący się identyfikuje i analizuje nową formę językową dostrzegając jej funkcję, cechy charakterystyczne i analogię z innymi znanymi strukturami, w skutek czego przypisuje jej znaczenie i zasady użycia. Struktury złożone są przyswajane, w zależności od stanu posiadanej wiedzy ucznia, całościowo lub są rozkładane na segmenty.

Dostrzeżenie zależności między przedstawionymi powyżej opisami i fazami nauki pozwala lepiej zrozumieć cel i charakter poszczególnych etapów pracy ze słownictwem. Wiedza ta może stanowić podstawę teoretyczną pozwalającą uzasadnić postępowanie zalecane w czasie kształcenia przyszłych nauczycieli języków obcych, którzy działają często intuicyjnie lub zgodnie z własnym przekonaniami o właściwości stosowania danej techniki (tzw. osobiste teorie nauczania). W oparciu o naturalne procesy przyswajania słownictwa można zaproponować etapy pracy ze słownictwem:

$>$ prezentacja nowej struktury i jej identyfikacja;

$>$ przypisanie znaczenia;

$>$ uświadomienie budowy i reguł funkcjonowania danej struktury;

$>$ utrwalenie struktury;

$>$ użycie struktury.

Zestawiając ze sobą wymienione powyżej modele: przetwarzania informacji, przetwarzania inputu, procedur dydaktycznych w nauczaniu języków obcych oraz pracy ze słownictwem można dostrzec następujące korelacje:

\begin{tabular}{|l|l|l|l|}
\hline $\begin{array}{l}\text { przetwarzanie informacji } \\
\text { (wg. Schmidt 1986) }\end{array}$ & $\begin{array}{l}\text { przewarzanie inputu } \\
\text { (wg. Vogel 1989) }\end{array}$ & $\begin{array}{l}\text { procedury } \\
\text { (wg. Lewicka 2006) }\end{array}$ & $\begin{array}{l}\text { przyswajanie struktury } \\
\text { leksykalnej }\end{array}$ \\
\hline zainteresowanie & input & sensybilizacja & prezentacja \\
\hline przyjęcie informacji & Dostrzeżenie formy & selekcja & identyfikacja nowej struktury \\
\hline analiza & Postawienie hipotezy & sematyzacja & $\begin{array}{l}\text { przypisanie znaczenia, uświado- } \\
\text { mienie budowy i reguł funkcjono- } \\
\text { wania }\end{array}$ \\
\hline zachowanie i reaktywacja & $\begin{array}{l}\text { testowanie hipotezy i } \\
\text { zachowanie } \\
\text { output }\end{array}$ & $\begin{array}{l}\text { memoryzacja i } \\
\text { kontekstualizacja } \\
\text { aplikacja }\end{array}$ & integracja i utrwalenie \\
\hline
\end{tabular}

Tabela 1: Zestawienie faz przetwarzania struktur językowych. 
Odwołując się do tych modeli można wysnuć wiele wniosków i implikacji dla nauczania struktur językowych, w tym leksyki.

\subsection{Faza prezentacji}

Model przetwarzania informacji podkreśla wagę zainteresowania - im bardziej jesteśmy ciekawi, tym wyższa gotowość aktywnego działania. Potwierdzają to obserwacje uczniów, którzy dużo chętniej i efektywniej opanowują słownictwo związane np. ze światem komputerów niż z ochroną środowiska.

W czasie naturalnego procesu przyswajania języka dostrzegane są te wyrażenia, które zwróciły naszą uwagę. Na lekcji języka obcego najczęściej to autorzy podręcznika i nauczyciele dokonują wyboru, które struktury staną się przedmiotem nauki, i tak organizują input, by skierować uwagę uczniów na wybrane zwroty (konstruktywiście są przeciwni takiemu postępowaniu i postulują, by każdy uczeń miał prawo do własnego wyboru struktur do przyswojenia). By uczeń mógł dostrzec daną strukturę musi ona zostać odpowiednio wyeksponowana lub uczeń sam musi ją uznać za wartą poddania analizie, a więc $w$ najczęstszych przypadkach uznać za ogólnie przydatną lub potrzebną dla realizacji konkretnego celu.

W czasie prezentacji materiału językowego nauczyciel stosuje techniki ułatwiające strukturyzację i zrozumienie tekstu, kierując równocześnie uwagę na wybrane jego elementy. Bardziej wpadają w ucho tudzież w oko te formy, które występują często lub są bardziej wyraziste. Jeśli tekst jest prezentowany ustnie, nauczyciel może posłużyć się odpowiednią intonacją, zaakcentowaniem czy powtórzeniem danego wyrażenia. $W$ tekście pisanym zwracamy uwagę na powtarzające się formy, częściej zauważamy wyrażenia, które są nam nieznane i utrudniają zrozumienie treści (zjawisko to występuje dużo rzadziej w czasie odbioru tekstu mówionego). Dodatkowo osoby prezentujące tekst mogą zastosować środki graficzne, np. podkreślenie, kolor.

Osobnym zabiegiem dydaktycznym jest takie skonstruowanie zadań do tekstu, by uczniowie byli zmuszeni rozpoznać dane wyrażenie jako niezbędne do jego rozwiązania. $Z$ tego wynika postulat, by jeszcze przed prezentacją tekstu uczeń był świadomy celu, dla którego go słucha czy czyta. Postępowanie to jest zgodne $z$ sytuacją $w$ naturalnym środowisku obcojęzycznym, kiedy odbiorca tekstu ma pewne z góry określone lub modyfikowane na bieżąco intencje czy oczekiwania wobec tekstu.

To co odróżnia naukę języka obcego od przyswajania języka w sytuacji naturalnej, to przyswajanie wyizolowanego słownictwa. Jest ono wprowadzane przez nauczyciela w postaci prezentowanych po kolei wyrażeń, których znaczenie jest objaśniane z pomocą różnych technik, np. podanie zdania kontekstowe- 
go, definiowanie czy podanie wprost odpowiednika w języku ojczystym. Uczniowie korzystają też z pomocy dydaktycznych, typu repetytoria i słowniki tematyczne z listami zwrotów obcojęzycznych i ich odpowiedników w języku ojczystym. Te ostatnie służą przejściu kolejnej fazy - przypisania znaczenia.

\subsection{Faza przypisania znaczenia}

Ponieważ warunkiem udanego przetworzenia struktury jest jej zrozumiałość, nauczyciel powinien zadbać o odpowiednią jakość prezentacji materiału językowego. W modelu przetwarzania inputu wiele miejsca poświęca się poziomowi przetwarzanego tekstu, który ogólnie określa się za Krashenem jako i+1 (Krashen, 1985: 2). Dzięki niemu uczeń dostrzega w swojej wiedzy lukę, którą może zapełnić przyswajając daną strukturę. To zaś możliwe jest tylko wtedy, jeśli kontekst, w jakim występuje nowa forma jest wystarczający do identyfikacji jej znaczenia, a dalej do rozpoznania jej cech morfo-syntaktycznych i reguł użycia. Oznacza to, iż musi ją otaczać odpowiednia ilość znanych struktur, tak by $w$ połączeniu z kontekstem sytuacyjnym można przypisać jej znaczenie. Swoistą rolę odgrywają tu wiedza ogólna ucznia i dotychczasowe doświadczenia, w tym znajomość innych języków. Dzięki nim uczeń łączy ze sobą poszczególne segmenty tekstu z informacjami pozajęzykowymi i odczytuje ich znaczenie (por. de Florio-Hansen, 1991: 341). Trudności sprawiają tu elementy leksykalne znaczeniowo ubogie i o niesprecyzowanym znaczeniu, np. partykuły oraz pojęcia o wysokim stopniu abstrakcyjności.

W wyniku znajomości opisanego procesu zaleca się stosowanie różnorodnych technik objaśniania słownictwa, wśród których podawanie od razu odpowiednika w języku ojczystym jest raczej ostatecznością. W pierwszej kolejności należy sięgać do środków napotykanych $w$ warunkach naturalnych, a więc odniesienie nowej formy bezpośrednio do jej denotatu (np. nazwanie konkretnego przedmiotu) lub $\mathrm{w}$ oparciu o tekst. W pozostałych przypadkach prezentacja powinna zawierać odpowiedni kontekst czy to językowy czy sytuacyjny umożliwiający uczniom odkrycie znaczenia danej formy (opis sytuacji, definiowanie, synonimy, itp.). Taki sposób objaśnienia słownictwa nie jest niczym obcym również w naturalnych warunkach, kiedy to bezpośrednio prosimy naszego rozmówcę o wyjaśnienie niezrozumianego zwrotu czy sprawdzamy go w słowniku. Sięganie do posiadanej wiedzy językowej wykorzystuje znajomość reguł tworzenia rodzin wyrazów oraz podobnych zwrotów o tym samym znaczeniu w innych językach.

Do doświadczeń językowych należy niewątpliwie język ojczysty. Sporo kontrowersji w temacie wprowadzania nowego słownictwa budzi kwestia tłumaczenia wyrażeń. Przeciwnicy uważają, że należy tworzyć bezpośrednie 
połączenia między nazwą a nazwanym obiektem i że odniesienie do języka ojczystego zaburza proces myślenia w języku obcym. W dodatku przypisywane odpowiedniki mogą być nieadekwatne, ze względu na różnice w cechach semantycznych. Jednakże rzeczywistość pokazuje, że niezależnie od metod stosowanych przez nauczycieli uczący się tak czy tak szukają macierzystych ekwiwalentów (por. Scherfer, 1988: 32). Język ojczysty jest bowiem naturalnym pośrednikiem w konstruowaniu znaczeń; wraz ze wzrostem stopnia zaawansowania językowego człowiek odrywa się od tego języka i aktywuje bezpośrednio zasoby wiedzy w języku drugim (Butzkamm, 1993: 124).

\subsection{Faza uświadomienia budowy i reguł funkcjonowania}

Proces przyswajania struktur językowych stanowi pewne kontinuum od analizy czysto semantycznej do szczegółowej analizy strukturalnej (Gass, 1997). Naukę słownictwa należy postrzegać jako proces, w którym po początkowej niepewności względem właściwego zrozumienia nowej struktury następuje coraz dokładniejsze uchwycenie znaczenia, łącznie z jej cechami konotacyjnymi i socjokulturowymi (Scherfer, 1988: 34). Nie każdy zrozumiany zwrot staje się przedmiotem procesów uczeniowych, albowiem zdarza się, że odebrana wypowiedź jest przetworzona na poziomie komunikacyjnym, ale nie przyczynia się do poszerzenia wiedzy. Tu należy widzieć kolejną rolę do spełnienia dla nauczyciela, który w sposób mniej lub bardziej świadomy skłania do pochylenia się ucznia nad danym wyrażeniem - bądź to przez zapytanie o jego znaczenie, bądź tworząc sytuację, w której uczeń musi rozpoznać to wyrażenie lub sięgnąć po nie w celu wykonania zadania.

Uczeń, który dostrzegł nowe wyrażenie stawia najpierw hipotezę, która w przypadku słownictwa odnosi się nie tylko do znaczenia, równie ważne są wymowa, pisownia oraz rozpoznanie cech morfo-syntaktycznych, a więc jaką jest częścią mowy, jakie inne formy tworzy i co one wyrażają (np. jak tworzy się formę mnogą danego rzeczownika, albo jak brzmi forma czasownika dla innej osoby). Nie bez znaczenia są informacje dotyczące łączenia się danej struktury leksykalnej z innymi w bardziej złożone struktury, np. połączenia przyimkowe, kolokacje, idiomy.

Testowanie hipotez może mieć miejsce przy ponownym rozpoznaniu struktury w kolejnych odbieranych wypowiedziach i porównanie, czy przypisane znaczenie jest aktualne w nowym kontekście, a także przez dostrzeżenie takiej samej reguły użycia. Proces ten może zostać znacznie zoptymalizowany na lekcji języka obcego przez odpowiednie kierowanie uwagi ucznia na właściwe elementy. Mogą to być bezpośrednie pytania o daną cechę struktury lub też zadania, które wymuszają receptywne lub ewentualnie częściowo 
reproduktywne posłużenie się zwrotem. Służą temu ćwiczenia, gdzie należy wybrać właściwy zwrot spośród podanych, np. wpisanie wyrażenia do luki w zdaniu, wykreślenie słowa niepasującego, dopasowanie do siebie zwrotów lub odpowiedzenie na pytanie wyrażeniem z tekstu.

Takie receptywne testowanie hipotez poprzedza zazwyczaj testowanie produktywne, polegające na aktywnym zastosowaniu poznanego wyrażenia w produkcji językowej (por. Vogel, 1989). Postępowanie to wymaga użycia w pełni struktury, do czego potrzebne są nie tylko znajomość formy i znaczenia, ale także jej funkcjonowania w ramach systemu danego języka lub tekstu. Rolą nauczyciela na tym etapie jest dostarczenie ćwiczeń utrwalających pozwalających przetestować nowe wyrażenia „z różnych stron”. Mogą to być ćwiczenia typu uzupełnienie rzeczownika w formie mnogiej, ćwiczenia na uzupełnienie tekstu nowymi wyrażeniami.

\subsection{Faza integracji i utrwalenia}

Wiedzę tworzą informacje zachowane w pamięci. Za przyswojone uznaje się te dane językowe, które zostały dostrzeżone, przetworzone i zintegrowane z istniejącym systemem wiedzy (tzw. intake, zob. Sharwood Smith, 1994). Kryteria odnośnie tego, które elementy zapamiętujemy lepiej są analogiczne do tych, według których prędzej je dostrzegamy, a więc przede wszystkim częstotliwość występowania lub uznanie za przydatne. Generalnie uczymy się chętniej i lepiej opanowujemy słownictwo, które jest nam bliskie, które jest często używane, oraz ma "daleki zasięg”, czyli takie wyrażenia, przy pomocy których można opisać wiele obiektów, sytuacji i zdarzeń w różnych sytuacjach komunikacyjnych (Scherfer, 1988: 29).

Zachowanie struktury $w$ pamięci jest związane z jej integracją z dotychczasową wiedzą, czyli umiejscowieniem jej w sieci informacji, jaką tworzy system wiedzy. Informacje, które próbujemy zapamiętać w wyizolowaniu, np. poprzez „wkuwanie na pamięć" listy słówek, zazwyczaj szybko zostają zapominane. Skuteczniejsze jest tworzenie relacji czy ciągów skojarzeń. Istnieje wiele różnych strategii memoryzacji słownictwa, spośród których można wymienić połączenia słowne, gdy słowa są zapamiętywane w typowych kontekstach językowych lub w zdaniach, łączenie słów w rodziny wyrazów, synonimy, antonimy, tworzenie pól semantycznych czy sieci skojarzeń wokół jakiejś sytuacji komunikacyjnej. Zadania oferowane na lekcji powinny wspierać reorganizację systemu wiedzy zachęcając do grupowania, klasyfikowania, uporządkowywania i kategoryzowania wyrażeń.

Dodatkowym wzmocnieniem jest udział wielu zmysłów, a więc wzroku (forma graficzna, obraz sytuacji), słuchu (forma dźwiękowa, odniesienie do 
fragmentów konkretnej rozmowy), także emocje związane bądź to z samym wyrażeniem bądź sytuacją, w której go poznaliśmy lub użyliśmy. Wielopoziomowe przetwarzanie informacji, a co za tym idzie głębsze zapamiętanie, oznacza tutaj: na poziomie werbalnym, sensorycznym, motorycznym, emocjonalnym (Engelkamp, 1985).

Długotrwałe zachowanie informacji wiąże się z procesem jej reaktywacji (por. Schmidt, 1986). Każdorazowe użycie struktury językowej powoduje ponowną aktywację nie tylko jej cech fonetycznych, graficznych, semantycznych i gramatycznych, ale też wzmocnienie śladów w pamięci, które dysponują mocą (zdolnością) receptywną, reproduktywną oraz produktywną (kreatywną; Szczodrowski, 2000). W zależności od tego, która zdolność będzie w jakim stopniu aktywowana, taki ślad pozostanie w pamięci. W tym kontekście trzeba odróżnić tzw. bierną $\mathrm{i}$ aktywną znajomość słownictwa, a więc czy uczeń potrafi daną strukturę jedynie rozpoznać (zrozumieć), czy także wykorzystać we własnych wypowiedziach.

Zachowanie struktur w pamięci i ich integracja z osobistym systemem wiedzy jest procesem bardzo indywidualnym. Zadaniem nauczyciela jest stworzenie dogodnych warunków, a więc dostarczenie licznych zadań, aktywujących rożne obszary i typy wiedzy. Są to niejednokrotnie te same ćwiczenia, które zostały wymienione przy etapie testowania hipotez. Ważne jest by aktywowały one odpowiedni kontekst językowy i sytuacyjny, by dotyczyły formy zarówno graficznej jak i dźwiękowej, by wymagały odwołania się do posiadanej wiedzy i ewentualnie osobistych doświadczeń.

\subsection{Faza użycia}

O ile w czasie utrwalanie słownictwa testuje się po kolei różne pojedyncze lub częściowo połączone aspekty nowych wyrażeń, o tyle na etapie jego zastosowania zakłada się, że stało się ono już integralną częścią posiadanej wiedzy $\mathrm{i}$ uczeń jest zdolny do posłużenia się nim w komunikacji językowej. Na lekcjach można zaobserwować, że zanim uczeń przejdzie do całkowicie swobodnego użycia, ma możliwość rozwiązania mniej lub bardziej sterowanych tzw. zadań (przed)komunikacyjnych. Mają one na celu odciążenie umysłu ucznia w warstwie treściowej, gdy uczeń może się skoncentrować głównie na werbalizacji myśli. Jako przykład takich zadań można podać streszczanie lub opowiadanie znanego tekstu, odpowiadanie na pytania otwarte czy tworzenie wypowiedzi ograniczonych ramami konkretnej omówionej wcześniej sytuacji.

Końcowym etapem nauki słownictwa jest jego zastosowanie w swobodnych wypowiedziach w dowolnym czasie i kontekście. Oczywiście należy mieć tu na względzie prawa działania pamięci. Wyrażenia nie używane dłuższy czas ulegają stopniowemu zapominaniu, dlatego dobrze jest stwarzać na lekcji okazje do 
ponownego ich użycia. Należy mieć też na względzie, iż zwroty testowane i używane głównie receptywnie nie będą zapewne wykorzystywane przez ucznia w produkcji własnej, albowiem ich ślad w pamięci straci swą moc produktywną.

Produktywne użycie wymaga aktywacji struktury na wielu poziomach i ich koordynacji. Przy tworzeniu wypowiedzi trzeba daną myśl zwerbalizować, czyli nieraz wybrać spośród kilku form tą, która jest właściwa dla konkretnej sytuacji czy relacji z rozmówcą. Wybór dotyczy często nie tylko tego jednego wyrażenia, ale automatycznie innych struktur, które trzeba następnie połączyć ze sobą z pomocą odpowiednich reguł morfo-syntaktycznych.

Faza zastosowania nowo poznanych wyrażeń leksykalnych to bardzo często najbardziej zaniedbana faza w nauczaniu języka obcego. Przez nauczycieli jest ona postrzegana jako pochłaniająca bardzo wiele czasu. Faza ta, szczególnie na początku nauki, trwa rzeczywiście długo ze względu na problemy uczniów z formułowaniem myśli i poprawnym łączeniem wyrazów, co wywołuje błędy gramatyczne, leksykalne i logiczne, na poprawę których trzeba znowu poświęcić niemało czasu. Produkcja pisemna jest często przesuwana poza ramy lekcji jako zajęcie do domu, jeśli dochodzi w ogóle do ustnego wypowiadania się na dany temat czy w danej sytuacji komunikacyjnej, to czyni to jeden lub dwóch uczniów. Szybciej jest odpytać pojedynczych słówek prosząc o podanie odpowiednika wyrażenia czy podając kontekst, który uczniowie uzupełnią brakującą formą leksykalną. Warto jednak pamiętać, że o ile wiele ćwiczeń i zadań utrwalających można wykonać w domu, także rozwijać sprawności receptywnych (także dzięki dostępnym dziś powszechnie nagraniom dla uczniów), to produkcja ustna może być kształcona jedynie w kontakcie z bardziej zaawansowanym językowo partnerem, którym najczęściej jest jedynie nauczyciel języka obcego.

\section{Podsumowanie}

Znajomość procesów przyswajania struktur językowych, ich przebiegu i determinantów pozwala na stworzenie uczniom optymalnych warunków do odkrywania nowego słownictwa i przetwarzania go z uwzględnieniem wszystkich cech potrzebnych do późniejszego jej użycia. Jakość analizy i trwałość zachowania struktury w pamięci zależy od form jej prezentacji oraz ćwiczeń językowych i zadań komunikacyjnych stosowanych przez nauczyciela. Powinny one umożliwiać pełne i wielopoziomowe przetworzenie zwrotów, co zapewni odpowiednie przygotowanie ucznia do ich użycia w przyszłych kontaktach obcojęzycznych zarówno w sytuacji edukacyjnej (egzaminy, kursy kontynuacyjne), jak i warunkach naturalnych. Wiedza ta jest także przydatna 
na nauczycielom, by móc nieraz spojrzeć krytycznie na oferowane materiały dydaktyczne, umieć je uzupełnić oraz opracować własne materiały w przypadku lekcji autorskich.

\section{BIBLIOGRAFIA}

Butzkamm, W. 1993. Psycholinguistik des Fremdsprachenunterrichts: natürliche Künstlichkeit von der Muttersprache zur Fremdsprache. Tübingen: Francke.

De Florio-Hansen, I. 1991. „FSU und ZSE. Ein Vergleich der Sprachaufnahmeprobleme". Praxis des neusprachlichen Unterrichts 4/1991: 339-345.

Engelkamp. J. 1985. „Die Repräsentationen der Wortbedeutung” (w) Handbuch der Lexikologie (red. Ch. Schwarze, D. Wundrlich) Königsstein/TS: Athenäum: 292-313.

Gass, S. M. 1997. Input, Interaction and the Second Language Learner. Mahwah, New Jersey: Lawrence Erlbaum Associates.

Huneke, H.-W., Steinig, W. 2002. Deutsch als Fremdsprache: eine Einführung. Berlin: Erich Schmidt.

Kesseler, H.J. 2004 Didaktische Strategien beim Wissenstransfer im Spannungsfeld von Bildungsdidaktischen und kommunikationswissenschaftlichen Ansprüchen. www. edoc.ub.uni-muenchen.de/archive/00003246/01/Kesseler_Hansjoachim.pdf DW 12.05.2006.

Komorowska, H. 2002. Metodyka nauczania języków obcych. Warszawa: Fraszka Edukacyjna.

Krashen, S. 1985. The Input Hypothesis: Issues and implications. London,New York: Longman.

Lewicka, G. 2007. Glottodydaktyczne aspekty akwizycji języka drugiego a konstruktywistyczna teoria uczenia się. Wrocław: Oficyna Wydawnicza Atut - Wrocławskie Wydawnictwo Oświatowe.

Pfeiffer, W. 1986. „Wissenschaftliche Grundlagen der Fremdsprachendidaktik”. Deustch als Fremdsprache IV: 215-219.

Raczyńska, M. 2007. „Kompetencje lingwistyczne, socjolingwistyczne, pragmatyczne i funkcjonalne w uczeniu się i nauczaniu języka według standardów Europejskiego Systemu Opisu Kształcenia Językowego" (w) Materiały z IV Międzynarodowej Konferencji Edukacyjnej „Przez Języki Obce do Sukcesu”, Ustroń: 169-175.

Sadownik, B. 1981. Implikationen der Zweitsprachenerwerbsforschung. Lublin: Wydawnictwo UMCS.

Scherfer, P. 1988. „Überlegungen zum Wortschatzlernen im Fremdspracheunterricht” (w) Aspekte des Lernens und Lehrens von Fremdsprachen (red. A. Rasch, M. Bludau, F. J. Zapp) Frankfurt nad Menem: Moritz Diesterweg Verlag: 28-51.

Schmidt, G. 1986. „Fremdsprachlicher Unterricht mit mehr Motivation - Übertragung didaktischer Teilkompetenzen auf den Schüler bei der Methode von Jean-Pol Martin". Die Bayerische Realschule 11/86: 16-20.

Sharwood Smith, M. 1994. Second Language Learning: Theoretical Foundations. Longmann. 
Fazy przetwarzania informacji językowych w nauce obcojęzycznego słownictwa

Szczordowski, M. 2000. „Glottokodematyka i jej zakresy badawcze” (w) Problemy komunikacji międzykulturowej. Lingwistyka, translatoryka, glottodydaktyka (red. B. Kielar, T. Krzeszowski, J. Lukszyn, T. Namowicz). Warszawa: Graf Punkt: 428-450.

Vogel, K. 1989. Aspekte der Lernersprache als Forschungskonzept des Zweitsprachenerwerbs. Göttingen

Wilczyńska, W., Michońska-Stadnik, A. 2010. Metodologia badań w glottodydaktyce. Wprowadzenie. Kraków: Avalon/Flair.

Wode, H. 1993. Psycholinguistik: eine Einführung in die Lehr- und Lernbarkeit von Sprachen. Ismaning: Hueber. 